\title{
Godt utført førstehjelp kan representere et vendepunkt for personer med selvmordstanker!
}

Ved Dag Willy Tallaksen og Johan Lindmark

\section{Denne artikkel har to hensikter. På den ene side vil vi peke på at det er påkrevet med økt innsats innen førstehjelp til personer i selvmordskrise. Dernest vil vi informere om at kurset "Førstehjelp ved selvmordsfare" er under revisjon. Dette inkluderer en tydeliggjøring av} førstehjelpsaspektet.

\begin{abstract}
Selvmordstallene i Norge er økende og det berører mange av oss. Mangelen på språk og trening i å snakke om selvmordstanker gjør at dette er et problem som lett underkommuniseres. Trening i å snakke om selvmordstanker er trolig en forutsetning for å få til større åpenhet. Kurset "Førstehjelp ved selvmordsfare" legger vekt på bevisstgjøring av holdninger og trening i å snakke om vanskelige tema. Vivat selvmordsforebygging ønsker at det skal bli like selvfølgelig å gripe inn ved selvmordskriser som det er å starte hjerte/lungeredning. For å få til dette kreves et krafttak innen utdanning av førstehjelpere. Kurset "Førstehjelp ved selvmordsfare" ble introdusert i Norge i 1998. Vi stå nå overfor den andre stor revisjonen av kurset. Denne gangen legges det enda tydeligere vekt på førstehjelpsaspektet. Betydningen av sikkerhet og tydelig lederskap i krisesituasjoner understrekes. En godt utført førstehjelpsintervensjon vil kunne representere et vendepunkt for den som står i fare for å miste sitt liv. Den interaktive undervisningen som har vært kursets varemerke videreføres. Dette er et av de mest anvendte selvmordsforebyggende kurs på verdensbasis. Norge er tidlig ute med denne faglige oppdateringen.
\end{abstract}

Suicide figures are increasing in Norway and it affects many of us. The lack of language skills and training in talking about suicide makes this a problem that can be easily under-communicated. Training in talking about suicide is probably a prerequisite for achieving greater openness. The ASIST workshop focuses on raising awareness of attitudes and practice in talking about difficult issues. Vivat selvmordsforebygging would like it to be equally self evident to intervene in suicidal crises as it is to start the heart / lung resuscitation. To achieve this requires a major effort in the education of first aid interventions. The ASIST workshop was introduced in Norway in 1998. We now face the second major revision of the workshop. This time it will be even more pronounced emphasis on the first aid aspect. The importance of security and clear leadership in crisis situations is emphasized. A well done first aid intervention could represent a turning point for those who are in danger of losing their lives. The interactive teaching that have been the workshop's trademark will be continued. This is one of the most used suicide prevention workshops worldwide. Norway is in forefront with this update.

LEVERT: 29/01-13 REVIDERT: 04/04-13 AKSEPTERT: 08/04-13
Det ser ut til at den positive utviklingen i reduksjon av selvmord her til lands de siste 15-20 årene er brutt, og at antall selvmord igjen øker. Det er særlig blant yngre personer og hos eldre menn at selvmordsratene øker (Nasjonalt Folkehelseinstitutt, 2012). Internasjonalt er omfanget av selvmord stort, og selvmord utgjør flere dødsfall på verdensbasis enn antallet personer som dør av krigshandlinger (World Health Organisation, 1999). I tillegg kommer all lidelse som er forbundet med selvmordstanker og selvmordsforsøk.

\section{Språkferdighet og åpenhet - hvordan lære dette?}

Det er grunn til å anta at selvmordstanker, selvmordsforsøk og selvmord representerer tema som er vanskelig å snakke om, trolig gjelder dette også for mange personer med helsefaglig utdanningsbakgrunn (Leira, 2003). Selv om utviklingen har brakt mer åpenhet når det gjelder å snakke om sårbare tema som seksualitet og misbruk, så er mangelen på ord tydelig når det skal snakkes om følelser knyttet til å ville avslutte eget liv. Våre erfaringer, både fra Vivat selvmordsforebyggings førstehjelpskurs og fra sorggrupper for etterlatte ved selvmord, tilsier at mangelen på nyansert språk for å uttrykke lidelse er en utfordring. Hvordan få til å formidle noe som er vanskelig å artikulere for seg selv og som er vanskelig å motta for tilhøreren? Slikt kan fort gjøre at en føler seg ille berørt, og det kan bli pinlig. Et betimelig spørsmål i denne sammenhengen kan derfor være; kan det være at mangelfullt ordforråd og lite trening i å snakke om eksistensielle kriser medvirker til at selvmord skjer, og at hjelp kommer for sent?

Åpenhet om livets skyggesider er trolig et gode. Det forventes at media skal bli bedre til å omtale selvmord på en balansert måte (Nybø, 2007). Likedan er det ønskelig at enkeltindivider bedre skal kunne sette ord på sine innerste tanker i møte med nærstående, behandlere og andre hjelpere. Men hvordan lære dette? Kurset "Førstehjelp ved selvmordsfare" kan være en god begynnelse, men det løser langt fra alle de utfordringer som er knyttet til økt åpenhet. I kurset gis det godt rom for å snakke om, og på den måten bli kjent med, egne holdninger til selvmord og hva de samme holdningene kan bety både for en selv og den som trenger hjelp for å overleve en selvmordskrise. Kurset gir også rom for å trene på hva som kan og må snakkes om i en krisesituasjon. Dette gjøres til dels i form av rollespill, noe svært mange deltakere har motstand mot, likevel er det disse elementer i kurset som i ettertid evalueres best (Sosial- og helsedirektoratet, 2007). Et interessant spørsmål i vår sammenheng blir derfor hvordan vi kan komme fram til at kurs i førstehjelp ved selvmordsfare oppnår samme popularitet som ordinære førstehjelpskurs. Trening i hjerte-lungeredning oppfattes trolig som en nødvendighet på slike kurs. Hva er det som gjør det mer skremmende å trene på å møte situasjoner som innebærer samtaler om selvmord? Det er grunn til å tro at trening hjelper til å utvikle mer adekvat atferd i krisesituasjoner (McConnell et al. 2006). Er det noen rimelig grunn til å anta at dette er annerledes ved selvmordskriser? Forskning viser at det er sammenheng mellom opplæring og vilje til intervensjon i selvmordskriser (Cross et al, 2010)(King et al 2000). Tilførsel av kunnskap, ferdighetstrening og bevisstgjøring av egne holdninger, vil trolig kunne bidra til at selvmordsnære medmennesker får rask og kompetent hjelp (Tallaksen et al., 2013).

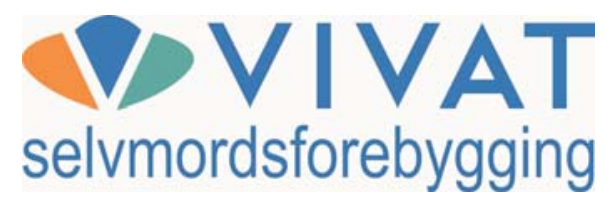




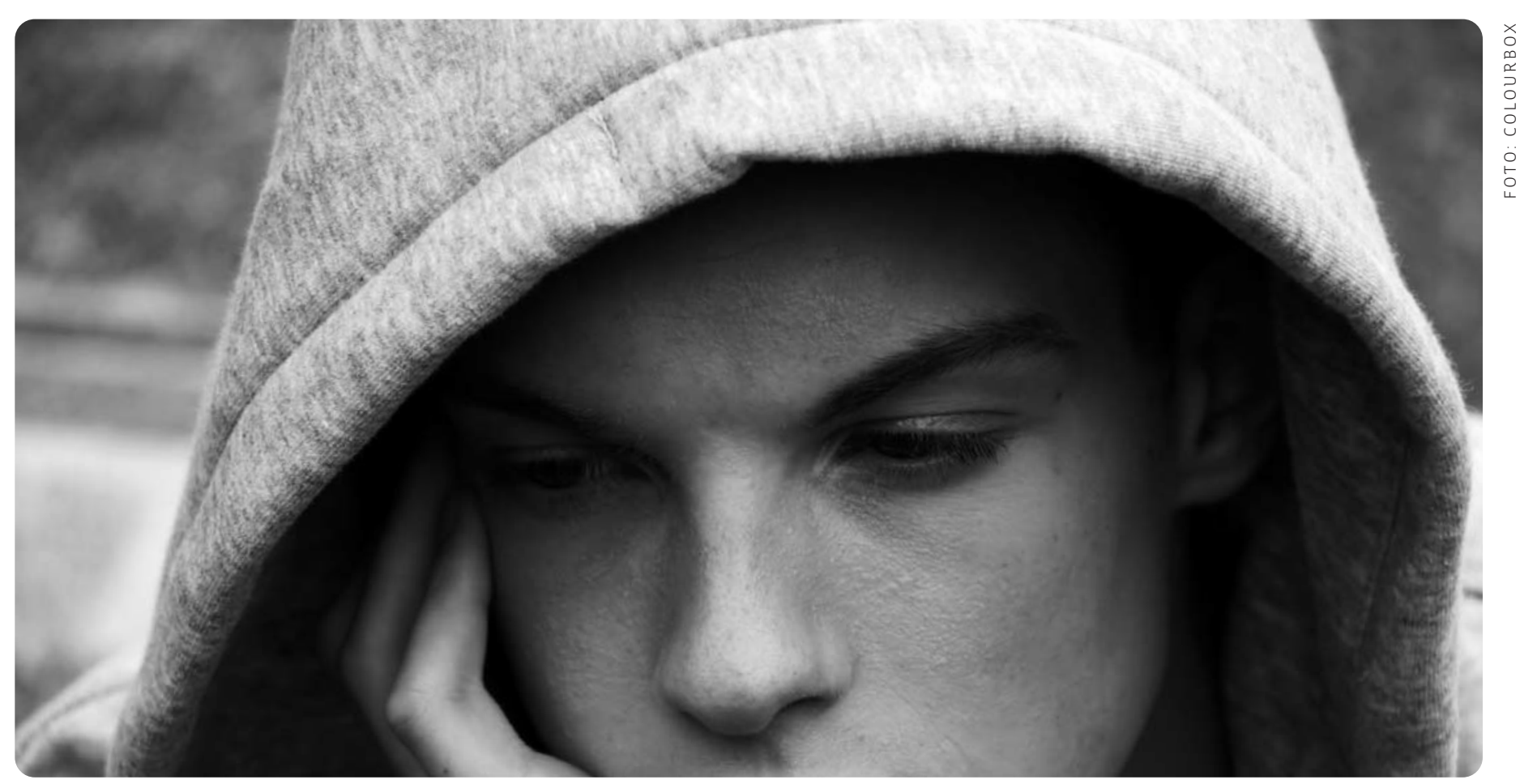

\section{Kurset "Førstehjelp ved selvmordsfare"}

Ildsjelene bak LivingWorks lanserte kurset ASIST - Applied Suicide Intervention Skills Training - tidlig i 80 årene. I Norge fikk kurset navnet "Førstehjelp ved selvmordsfare", og har vært i bruk siden 1998. Her til lands har nå mer enn 23000 personer deltatt på kurset, og på verdensbasis har mer enn 1 million deltakere gjennomført opplæringen (LivingWorks, 2013). Førstehjelpskurset ble tatt i bruk som en del av "Handlingsplan mot selvmord 1994-2000". Kurset er utviklet med basis i det beste man har av kunnskap innen områdene epidemiologi, selvmordsforebygging, kriseintervensjon, pedagogikk og oppbygging av standardiserte undervisningsprogrammer. Siden introduksjonen har driften og utviklingen av kurskonseptet vært organisert i Vivat selvmordsforebygging.

\section{Et krafttak knyttet til førstehjelpsinnsats er påkrevet}

Vår erfaring er at selvmord og selvmordshandlinger dessverre ikke utløser den samme respons og akuttinnsats som andre dødelige sykdommer. Vi vet f.eks. at innsatsen for å få i stand leteaksjoner etter selvmordsnære personer kommer sent i gang, senere enn for personer som ettersøkes på annen bakgrunn (Aarsæther, E. 2011). Når vi også vet at den suicidale intensjon for enkelte personer kun er sterk nok til å gjennomføre selvmord i svært korte tidsspenn (Mehlum, L. 2012), er dette uakseptabelt. Utsettes eller forhindres selvmordshandlingen vil dødsintensjonen ofte avta som en konsekvens av at tiden går. Vårt ønske er at selvmordsnære personer behandles med like stor intensitet og omsorg som intensivpasienter. De befinner seg i livsfare. Møtet med profesjonelle hjelpere er ingen garanti for at selvmordstruede og selvskadende personer blir behandlet i tråd med hva som ansees som "best practice". Om dette hadde vært en pasient med brystsmerter eller pusteproblem, ville en tilsvarende kunnskapsmangel trolig vært høyst kritikkverdig. Innen psykisk helsevern og kommunal helsetjeneste har det de siste årene pågått arbeid for å forbedre innsatsen i form av tydelige rutiner for oppfølging og behandling av selvmordsnære mennesker (Herrestad et al., 2012). Nå mener vi tiden er moden for at også førstehjelp og annen akuttinnsats i møte med selvmordsnære personer gis en faglig oppjustering. Det er kjent at noen selvmordsnære og selvskadende mennesker opplever å bli behandlet som uvelkomne, ja nærmest som om de stjeler tid og oppmerksomhet fra andre og viktigere oppgaver (Heiermark, 2004). Det finnes beretninger fra personer som er blitt suturert uten anestesi, trolig som en slags misforstått straff. Ordinært kyndige førstehjelpere/førstelinjemedarbeidere er for ofte ukyndige i møte med selvmordsnære mennesker (Moe et al, 2007). Med det store antall personer i en befolkning som til enhver tid plages med selvmordstanker må det arbeides fram en helt annen bevissthet på dette området. "Feil" eller manglende behandling kan i verste fall føre til mer plager og utvikling av kronisk suicidalitet. Det er trolig lite som skal til - et kurs i førstehjelp ved selvmordsfare vil for mange kunne utgjøre den nødvendige forskjellen. Tilførsel og kontinuerlig oppdatering av førstehjelpskunnskaper på lik linje med det som gjøres ved hjertelungeredning vil være et verdifullt bidrag (Cross et al., 2010). 
Her er mye å lære fra hvordan American Heart Association (2013) har gått fram for å utbre sitt resucitasjonsbudskap. Som person i fare/pasient er det trolig godt å bli møtt av noen som er forberedt på å ta imot deg når du har det vanskelig, og vi har forskning som sier at dette også kan motvirke kronisk suicidalitet (Grøholt, B., 2007). Vivat selvmordsforebygging mener at tiden er moden for et krafttak innen førstehjelp til personer i selvmordskrise.

\section{Revisjonen av kurset "Første- hjelp ved selvmordsfare"}

Vivat selvmordsforebygging står nå foran en revisjon av kurset "Førstehjelp ved selvmordsfare" som vil bety endringer for hvordan kurset gjennomføres og hvilke kunnskaper som formidles. Fortsatt er kurset et standardisert program, men denne gang med noe mer mulighet for "skreddersøm", slik at kurset bedre kan imøtekomme enkeltgrupper, som urbefolkninger og militæret. Kurset krever fortsatt ingen forkunnskaper og er åpent for alle over 18 år som er villige til å gå inn i utfordrende møter med selvmordsnære medmennesker. Ved den kommende revisjonen vil det bli lagt tydelig vekt på førstehjelpsaspektet.

\section{Sikkerhet først - redde liv}

Den selvmordnære personens sikkerhet er nå gjort til første trinn i hjelpeprosessen. Dersom selvmordshandlinger pågår, eller dersom personen ikke er i stand til å samarbeide, er første ledd i hjelpeprosessen å etablere kontakt med det profesjonelle hjelpeapparatet. I kurset formidles informasjon om hvilke hjelpeinstanser som finnes lokalt og på spesialistnivå. I den nye versjonen av kurset benyttes det en liste som deles ut til deltakerne om hvem og hvilke hjelperesursser som finnes i det aktuelle lokalsamfunn. Mange vil oppdage at det er flere resusser enn man er klar over. En langsiktig idé med kurset er å få deltakerne til å bidra til at disse samarbeider bedre. Ikke ulikt det som forventes i Samhandlingsreformen (Meld. St. 47 (2008-2009) 2008). Dersom det tar tid å bringe den selvmordsnære i kontakt med adekvat hjelp, formidler kurset budskap om å etablere en eller annen form for kontinuerlig overvåking inntil det profesjonelle hjelpeapparat kan overta. Den enkeltes autonomi må settes midlertidig til side for å redde liv. Førstehjelp betyr også lederskap. Det er et faktum ved hjerte/lungeredning, som ved intervensjon i selvmordskriser. Lederskap i en kort periode er nødvendig, og i samband med selvmordsatferd kan tydelig ledelse i situasjonen oppleves godt av personen i fare, og det kan i seg selv formidle håp om at situasjonen kan bli bedre.

En kritikk som har kommet mot kurset er at ukyndige hjelpere kan komme i en situasjon der de blir ansvarlige for personer med svært komplisert problematikk. I det reviderte kurs understrekes at førstehjelperens ansvar er avgrenset til den innledende fase og inntil annen hjelp er på plass. Lovverket pålegger alle borgere å yte hjelp til nødstette inntil det profesjonelle hjelpeapparat er på plass. Ingen av oss ville vel forlate en person i livsfare inntil kvalifisert hjelp kan overta? Loven gjelder selvsagt også ved selvmordshandlinger, men her må muligens en holdningsendring til. Vi må slutte å uten videre anta at selvmordsforsøkere ønsker å dø. Det man med rimelig sikkerhet kan hevde er at de ønsker endring (Williams, M., 2001).

\section{Sikkerhet, risikofaktorer og - vendepunkt}

Når den umiddelbare fare er avklart, legger kurset, som tidligere, vekt på en gjennomgang av risikofaktorer. Den psykiske smerte, planlegging av selvmordshandlinger, tidligere selvmordsatferd, bruk av rusmidler, eventuelle medikamenter og tidligere psykisk lidelse blir belyst. Dette avsluttes med en vurdering av hva som kan/skal gjøres for å etablere sikkerhet mot selvmordshandlinger og hva den selvmordsnære selv kan bidra med i et avgrenset tidsrom. Ved denne oppsummeringen vil mange hjelpere erfare at den selvmordsnære selv ser at livet står i fare, og mange ønsker nå hjelp til å leve videre.
Kurset bygger på den oppfatning at den selvmordsnære ikke primært søker døden, men ser ingen annen utvei enn selvmord for å slippe bort fra en ekstremt smertefull livssituasjon. Ved å la den selvmordsnære fortelle og ved å lytte til historien som fremkommer, vil det i seg selv representere håp og lysning. Ved "vellykket" førstehjelp vil mange kunne erfare at de står ved et vendepunkt. Livet er verdt å beskytte. Fortsatt vil tidligere kursdeltakere kjenne igjen innholdet, men språket og fokus endres noe. Begrepene lytt til historien, uro og kaos (fra engelsk: turmoil) og vendepunkt introduseres i den reviderte versjonen av kurset. De utfyller begrepene "ambivalens" og "lytt til grunner for å ville dø og leve". De samme interaktive undervisningsmetodene med stort innslag av rollespill benyttes fortsatt.

\section{Oppfølging}

Førstehjelpsintervensjonen avsluttes med å lage en plan for hva som kan gjøres for å beskytte livet. Hva ønsker den selvmordsnære, hva kan gjøres, hvilken hjelp er tilgjengelig og akseptabel, hvem kan kontaktes på kort og lang sikt? Dette er eksempler på hva som må avklares. En slik plan er ikke sterkere enn det hovedpersonen selv kan stå for, og ingen må forlates før kontakt med hjelpeapparat og/ eller familie er etablert.

En førstehjelpsintervensjon kan ta alt fra noen minutter til flere timer, men slik er førstehjelp. Etter hvert må førstehjelpsrelasjonen avsluttes på en verdig måte. Vellykket førstehjelp ved selvmordsfare kan oppleves svært tilfredstillende både for den selvmordsnære og hjelper. Følsomme tema er løftet fram og snakket om, det kan være at noe av det partene blir enige om skal følges opp på sikt. Kurset formidler at de involverte kan møtes igjen på et senere tidspunkt for å snakke om dette. Kurset avsluttes med et situasjonsspill hvor søkelys settes på hvordan det kan oppleves å bli hjulpet, og hvor hjelperne blir utfordret til å kjenne på hvor langt den enkelte vil strekke seg som hjelper. Samarbeid i lokalsamfunn blir også belyst. 


\section{Avslutning}

Heldigvis er selvmord og selvmordsforsøk relativt sjeldent. Derimot er selvmordstanker mer hyppig enn vi vanligvis tenker over. Seks prosent av oss har hatt alvorlige tanker om å ta sitt liv de siste tolv måneder (LivingWorks, 2004). Det er ikke usannsynlig at vi møter på en slik person, eller at det kan være en av oss som i en periode har det slik. Å bli møtt av en som tør å snakke om selvmord på en strukturert måte, og med den lidendes smerte i fokus vil trolig oppleves som godt og håpefullt. Det er slike medmennesker førstehjelpskurset håper å bringe inn i lokalsamfunnet. Vivat selvmordsforebygging er opptatt av å medvirke til å skape lokalsamfunn som kan virke beskyttende mot selvmord. På samme måte som kunnskap om resucitasjon gjør at liv reddes ved hjertestans, mener Vivat selvmordsforebygging at inngripen ved selvmordsatferd kan redde liv og forebygge lidelse. Fortsatt er det ikke mange nok med førstehjelpsbakgrunn som kan gripe inn i selvmordskriser. Det er her Vivat selvmordsforebygging håper på et krafttak.

Dette er noe av det vi ønsker å bidra med i årene som kommer. Visjonen er lokalsamfunn som gjør sitt ytterste for å forebygge selvmord og yte god og rask hjelp til dem som trenger det. I 2013-14 vil Vivat selvmordsforebygging ha fokus på å implementere de endringer som her er omtalt.

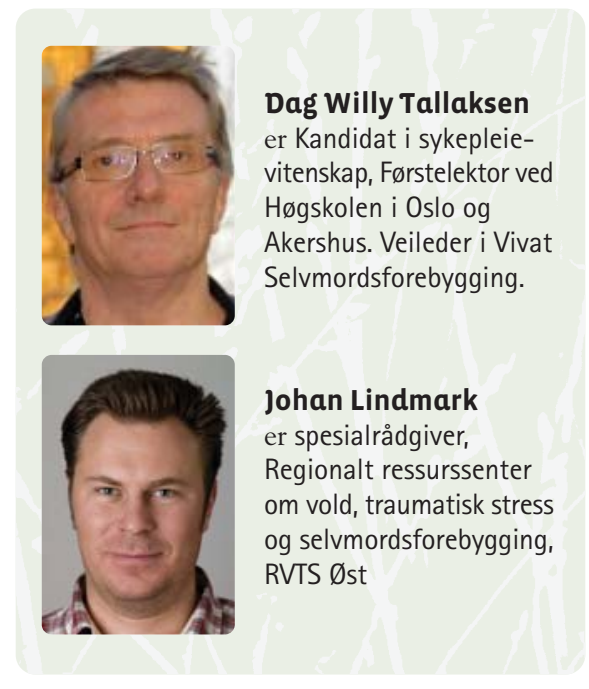

\section{Referanser}

Aarsæther, E. (2011). Veileder. Redningstjeneste og personer med økt selvmordsrisiko. Oslo: Norsk Folkehjelp Sanitet.

American Heart Association. (2013). Webside. Hentet fra http://www.heart.org/HEARTORG/

Cross, W., Matthieu, M.M., Lezine, D. \&t Knox, K. L. (2010). Does a brief suicide prevention gatekeeper training program enhance observed skills? Crisis. 31(3), 149-159.

Grøholt, B. (2007). Unge og gjentatte selvmordsforsøk. Suicidologi 12 (3), 8-11.

Heiermark, I. (2004). Selvskading - å leve med seg selv og andre. Tidsskrift for psykisk helsearbeid. 1(3), 49-56.

Herrestad, H. \& Larsen, K. (2012). Kartlegging, observasjon og vurdering av selvmordsrisiko. RVTS-øst. Hentet fra http://ost.rvts.no/Images/ assets/ dokuments/ost/vurdering $\% 20 a v \% 20$ selvmordsrisiko\%20jan2012.pdf
King, K.A. \& Smith, J. (2000). Project SOAR: a training program to increase school counselors' knowledge and confidence regarding suicide prevention and intervention. J Sch Health. 70(10), 402-406.

Leira, H.K. (2003). Det gode nærvær: kulturens psykologiske betydning. Bergen: Fagbokforlaget. LivingWorks. (2004). Suicide Intervention Handbook. Calgary: LivingWorks Education.

LivingWorks. (2013). A Brief History - The formation of LivingWorks the Business. Hentet fra http: //www.livingworks.net/page/A\%20 Brief\%20History

McConnell, A. \&t Drennan, L. (2006). Mission Impossible? Planning and Preparing for Crisis. Journal of Contingencies and Crisis Management, 14(2), 59-70.

Mehlum, L. (September, 2012). Selvmordsforebygging - hvilke tiltak har effekt? Forelesning ved Høgskolen i Oslo og Akershus, Kjeller. 10. sept. 2012.

Meld. St. 47 (2008-2009). (2008). Samhandlingsreformen. Rett behandling - på rett sted -til rett tid. Oslo: Helse- og omsorgsdepartementet.

Moe, A. \& Ribe, K. (2007). Selvskadingens dynamikk. Oslo: Universitetsforlaget.

Nasjonalt folkehelseinstitutt. (2012). Helsetilstanden i Norge: Selvmord og selvmordsforsøk. Oslo: Nasjonalt folkehelseinstitutt. Hentet fra http://www. fhi.no/faktaark. Sist oppdatert 05.12.2012.

Nybø, R.K. (2007). Fra tabu til tema. Kristiansand: lj-forlaget.

Sosial- og helsedirektoratet. (2007). Evaluering av undervisningsprogrammet Vivat. Sluttrapport. Oslo: Rambøll Management.

Tallaksen, D.W., Bråten, K., \&t Tveiten, S. (2013). "...You are not particularly helpful as a helper when you are helpless". Vård i Norden. Nordic Journal of Nursing Research. 33(1),46-50.

Williams, M. (2001). Suicide and attempted suicide. London: Penguin Books.

World Health Organisation. (1999). Figures and Facts about Suicide. Geneva: WHO. Hentet fra http:// whqlibdoc.who.int/hq/1999/WHO_MNH_MBD_99.1.pdf

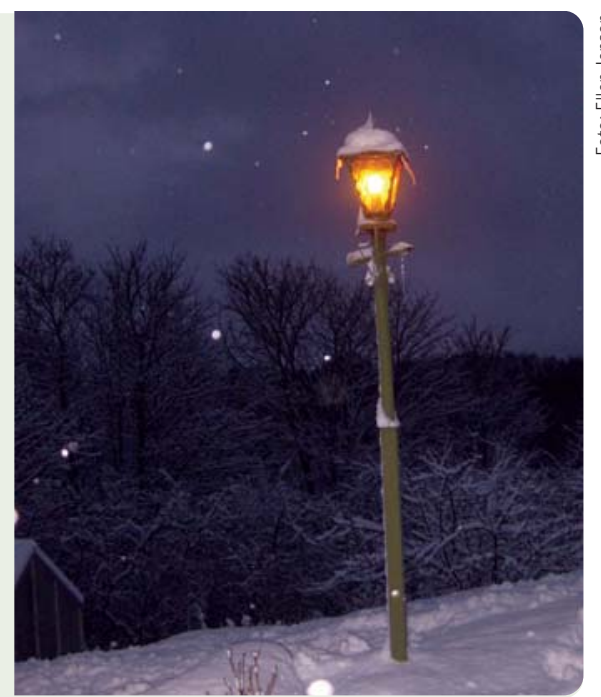

\section{Kandidater til Olafs Minnepris 2013}

Olafs Minnepris er etablert og deles ut av Stiftelsen Olafs Minnefond til forebygging av selvmord blant unge. Prisen tildeles som en anerkjennelse til en person som har bidratt med fremragende vitenskapelig arbeid eller kunnskapsformidling innenfor feltet selvmordsforebygging blant barn og ungdom. Prisen deles ut hvert år, fortrinnsvis i forbindelse med markering av Verdensdagen for selvmordsforebygging, 10. september. Prisen består av en bronsestatue og et diplom. Et fagutvalg ledet av professor dr med Lars Mehlum, forestår innstillingsarbeidet av kandidater til prisen. For mer informasjon se www.olafsminne.org.

Forslag til kandidater med navn på kandidaten, kort begrunnelse og navn på forslagstiller kan sendes på e-post til advokat Jon Schultz, js@legale.no innen 13. mai, 2013. Vennligst benytt skjema som kan lastes ned fra www.olafsminne.org.

Stiftelsen Olafs Minnefond til forebygging av selvmord blant unge www.olafsminne.org 